\title{
Experimental Study for Cultivating College Students' Sports Motivation in Sport Education Model
}

\author{
Yuehong Liang1, Jiling Zhang1, Yingbo Cui ${ }^{2}$, Ren Yuan' \\ ${ }^{1}$ Sports Department, Hebei University of Engineering, Handan, China \\ ${ }^{2}$ School of Physical Education, South China Normal University, Guangzhou, China \\ Email: liangyuehong8@163.com
}

Received 22 May 2016; accepted 1 August 2016; published 4 August 2016

Copyright (C) 2016 by authors and Scientific Research Publishing Inc.

This work is licensed under the Creative Commons Attribution International License (CC BY). http://creativecommons.org/licenses/by/4.0/

(c) (i) Open Access

\section{Abstract}

The paper analyzes the sport motivation change of students before and after sport education model by setting and implementing sport education model, which takes volleyball elective course in university for example. Sport education volleyball season model is adopted in this paper. Questionnaires were sent to respondents in experimental class before and after the experiment. Finally, statistical analysis was performed after qualified questionnaires were collected. After sport education model experiment, students' self-determination index was significantly higher than before $(p<0.01)$. The self-determination index between freshman and sophomore, male and female students has no differences after sport education model experiment $(p>0.05)$. Test indicated that freshman' external regulation motivation was more obviously than sophomore $(p<0.05)$; there is significant difference between male and female students' identified regulation motivation $(p<$ 0.05). Sport education volleyball season model enhances students' intrinsic motivation of sports, and meets students' psychological need to inspire their participation in physical education. Sport education model is applicable to all students. Thus, the result helps to popularize the sport education model.

\section{Keywords}

Sport Education Model, College Students, Sports Motivation

\section{Introduction}

The cultivation of students' sports motivation is an important research focus in the physical education field in

How to cite this paper: Liang, Y. H., Zhang, J. L., Cui, Y. B., \& Yuan, R. (2016). Experimental Study for Cultivating College Students' Sports Motivation in Sport Education Model. Advances in Physical Education, 6, 169-177. 
the world over the past twenty years. Sport motivation research result from the low sport motivation level of adolescent students which lead to serious social phenomenon and the factors of risk behaviors of high school students in 1999 survey shows that $81 \%$ of students do not participate in exercise class (CDC, 1999), besides in physical education students are often absent from class and become undisciplined (Ntoumanis et al., 2004). Since then, the United States started to study on sports motivation, with the increase of the experimental study all over the world. The result has been proved that motivation plays a vital role to provide sports experience of students (Kinchin, 2001). Sport Education Model (SEM) is considered a perfect model to develop students' motivation (Wallhead \& Ntoumanis, 2004; Perlman \& Goc Karp, 2010).

\subsection{Autonomous Motivation}

Autonomous motivation or motivation is based on self-determination theory (SDT) proposed by Deci and Ryan (1995). Self-determination theory aims to promote man's all-round development, cultivating individual behavior motivation and the formation of personality through the behavior of self-discipline (Ryan, Kuhl, \& Deci, 1997). Self-determination theory focused on behavior of human with volition and degree of self-determination (Deci \& Ryan, 2000). Motivation is regard as a reflection of individual's related goals and to meet the three primary psychological needs_-autonomy, competence, and social relatedness. Self-determination theory arrange the motivation as: intrinsic, extrinsic, and amotivation according to the degree of the three psychological needs. The advanced form of motivation is from intrinsic, which represents the behavior is spontaneous to achieve one's goal and it will not affected by unexpected events. Individuals intrinsically motivated to perform an activity will participate in that activity spontaneously and without any overt contingencies. Alongside intrinsic motivation lie three forms of extrinsic motivation: identified regulation, introjected regulation, and external regulation (Deci \& Ryan, 2000).

Identified regulation is a motivational construct that lies adjacent to intrinsic motivation and represents the most autonomous form of external regulation. This form of motivation reflects engaging in a behavior because it satisfies a personally relevant goal-for example, a person who takes exercise everyday in order to keeping healthy. Introjected regulation is adjacent to Identified regulation, which is reflected in the perception of the behavior of the internal pressure, such as avoiding the depression, or in order to obtain the team's self-esteem and pride, Introjected regulation also be recognized as interiorization form of cultivate motivation. External regulation that arranged in the terminal of motivation, it can reflect that the behavior of participation is just forced by external conditions or rewards, praises, pressures by other people. Completely different from intrinsic motivation the amotivation refers the Motivation form which lacks internal and external incentives and the desire of participation also represents a complete absence of autonomy and volition (Deci \& Ryan, 2000).

The developing from motiveless to intrinsic motivation originally in the important three basic psychological needs for psychological growth and well-being: 1) autonomous, 2) competence, and 3) relatedness. Autonomy is a conscious act according to the individually experience, Competence is understood as a perception of being able to demonstrate success within a given context. Relatedness is defined as having a connection with peers who are deemed significant to the student. In a certain degree, the realization of the act meets the psychological needs, the individual will experience a higher level of motivation, and thus produce more positive results, such as the enjoyment of sports (Haerens et al., 2010) and the intention to participate in sports movement (Ntoumanis et al., 2004). Students may prioritize one need or a combination of needs as influential for their motivation, but none of them to be considered useful than the other in the psychological needs. Therefore, students should be provided with more well-being physical education program, in order to develop their intrinsic motivation (Markland, 2005).

\subsection{Sports Education Model}

The Sports Education Model (SEM) is created by Siedentop (1994), and the SEM provides a more realistic and abundant sports experience for boys and girls in the school physical education environment. To achieve this "authenticity of experience”, Siedentop integrated six key features of institutionalized sport within the model. These features including affiliation, seasons, formal competition, record keeping, festivity, and post season. The work procedure is similar to a professional sports season. The team affiliation concept of youth sport is also replicated with students remaining on the same team for the duration of the season. The season is phased around levels of formal competition, with early lessons focused on preseason preparations including team management 
and game practices and latter lessons devoted to game play. Record keeping is embedded within the season with points kept for team game scores, fair play, and team management. These points are promoted to develop a sense of festivity and contribute toward a culminating event. As the season progresses, the teacher shifts from using more direct teaching styles to student-centered pedagogy as responsibility is diverted to students through the use of roles such as coach, trainer, equipment manager, or referee. Through these features, SEM could "educate students to be players in the fullest sense and to help them develop as competent, literate and enthusiastic sports people”.

Recent years, a large number of experimental studies have been carried out, the sports education model has been proved that students' active participation in sports and positive emotional effects which include the increase of the cognitive concept of students' fun, interest and enjoyment. And the resultsof positive emotion research also promote the structural change of the physical education; also enable students to follow the direction of motivation, providing the support of psychological needs, competence and relatedness (Perlman \& Goc Karp, 2010). Recent evidence suggests that the most effective sports education is reflected in the relatedness (Perlman, 2011) and competence (Spittle \& Byrne, 2009).

In addition, the effect of the research has more effective results to increase physical activity of students in the leisure time (Wallhead, Garn, \& Vidoni, 2014), and also improve participation motivation of sports of students who without motivation (Wallhead et al., 2013). Perlman (2010) indicated that, physical education can obviously increase the enjoyment and satisfaction of cooperation during class of those students without motivation (Perlman \& Goc Karp, 2010).

In China, students' lack of sports motivation is common. Recent years, most of the research is confined to the circumstance, or influence factors of students' sports motivation level, and so on. Few experimental researches can be found showing the lack of experimental studies. That means, we do not have much experimental experiences in practical. The motivation is a key factor, which is influencing the students' learning results. Therefore, it is very important to offer a sports class to students within motivation (Chen, 2001). The experimental as taking course of volleyball in college for example and the study focus on how to use sports education model to effect students' motivation.

\section{Methods}

\subsection{Participants and Setting}

The objects of study are students who taking volleyball for option class in University, including 122 freshmen and 114 sophomores (72 female and 164 male). The age of objects ranges from 18 to 23 with a mean age of 19.7. Student has one PE class in 2 hours per week and total 36 hours in the whole semester. The sports model adopt season racing way to arrange student's game. All students will take questionnaires at first week and when they finish their class in the end of semester they take another questionnaire.

\subsection{Sport Education Seasons}

In the curriculum of volleyball sport education, Teachers implemented the sports education season model under the experimental conditions (Hastie, 2000). SEM is divided into five stages (Table 1). The early stages dedicated to team players selection and role responsibilities, skills practices, and tactics and the latter lessons being committed to scrimmage and formal game-play situations (Hastie, 2000). The first phase is focused on team management (lessons 1): The first class has laid the foundation for the entire season. In this stage, coach selected by professor and team player determined their roles and work by their-self. In particular, the process of selection had highly flexibility, teacher helps students to solve issues base on their facts and all roles taken by students such as coach, judgment and recorder had being through whole semester. The second phase focuses on volleyball skills such as passing, dig pass, spiking. Teachers give guidance according to the different level and different grade (Lessons 2 through 3). The third is the preseason stage (lessons 4 through 7): According to the technical characteristics of students in the team, teachers arrange un-replaceable setter and attacker, and help students to improve the specific skills and tactical training in six different positions. Team member works together to complete the task within the team or among teams. The fourth stage is a formal tournament (lessons 8 through 15): In this phase, students will get huge improvement on role and performance in team and they will have good communication and teamwork. In end of tenth week, the match will be hold, and the position of coach, judgment 
Table 1. Sport education season chart.

\begin{tabular}{|c|c|c|c|}
\hline Lesson & Content & Teacher's role & Students' roles \\
\hline 1 & $\begin{array}{l}\text { Introduction rules to game } \\
\text { Beginning skills } \\
\text { Skills testing team } \\
\text { Announcement }\end{array}$ & $\begin{array}{l}\text { Class leader } \\
\text { Present team } \\
\text { lists } \\
\text { Discuss roles } \\
\text { Discuss fair } \\
\text { play }\end{array}$ & $\begin{array}{l}\text { Participant } \\
\text { Determine team roles } \\
\text { Determine team name }\end{array}$ \\
\hline $2-3$ & $\begin{array}{l}\text { Whole class skill instruction } \\
\text { Practice volleyball competition } \\
\text { strategy }\end{array}$ & Class leader & Participant \\
\hline $4-7$ & $\begin{array}{l}\text { Pre-season train } \\
\text { Players learn and practice duty roles } \\
\text { Tactical training }\end{array}$ & $\begin{array}{l}\text { Head coach } \\
\text { Referee } \\
\text { advisor }\end{array}$ & $\begin{array}{l}\text { Coaches, players, referee, recorder learn duty role } \\
\text { Setter, attacker learn position role }\end{array}$ \\
\hline $\begin{array}{l}7 \\
\text { Weekends }\end{array}$ & Class competition & $\begin{array}{l}\text { Program } \\
\text { manager }\end{array}$ & $\begin{array}{l}\text { Spectators, coaches, players, referee, recorder learn duty role } \\
\text { Setter, attacker learn position role }\end{array}$ \\
\hline $8-15$ & Formal competition & $\begin{array}{l}\text { Head coach } \\
\text { Program } \\
\text { manager }\end{array}$ & $\begin{array}{l}\text { Coaches, players, referee, recorder learn duty role } \\
\text { Setter, attacker learn position role }\end{array}$ \\
\hline 10 & $\begin{array}{l}\text { Formal competition among the } \\
\text { classes }\end{array}$ & $\begin{array}{l}\text { Program } \\
\text { manager }\end{array}$ & $\begin{array}{l}\text { Coaches, players, referee, recorder learn duty role } \\
\text { Setter, attacker learn position role }\end{array}$ \\
\hline $16-17$ & Play-offs & $\begin{array}{l}\text { Program } \\
\text { manager }\end{array}$ & $\begin{array}{l}\text { Coaches, players, referee, recorder learn duty role } \\
\text { Setter, attacker learn position role }\end{array}$ \\
\hline 18 & $\begin{array}{l}\text { Championship in class } \\
\text { Awards } \\
\text { Presentations }\end{array}$ & $\begin{array}{l}\text { Program } \\
\text { manager } \\
\text { Awards } \\
\text { ceremony } \\
\text { Master of } \\
\text { ceremonies }\end{array}$ & $\begin{array}{l}\text { Coaches, players, referee, recorder learn duty role } \\
\text { Setter, attacker learn position role }\end{array}$ \\
\hline $\begin{array}{l}18 \\
\text { Weekends }\end{array}$ & $\begin{array}{l}\text { Class final game } \\
\text { Awards } \\
\text { Presentations }\end{array}$ & $\begin{array}{l}\text { Program } \\
\text { manager } \\
\text { Master of } \\
\text { ceremonies }\end{array}$ & $\begin{array}{l}\text { Spectators, coaches, players, referee, recorder learn duty role } \\
\text { Setter, attacker learn position role }\end{array}$ \\
\hline
\end{tabular}

Note: SIMS was administered during lessons 6 for skill phase, and during lessons 11 through 13 for officiating and game play phases.

and recorders will be regulated. Finals stage (lessons 16 through 18): the predominant factor of students' scores is based on students' performance during the game. The eighteenth weekend, a final match will be held, all the students in experimental classes will be audience. All of the 236 students in the study will participate in the semifinals in class and the finals among classes. The teacher guide the strategy to maintain the consistency of the movement education structure, including the team work, record keeping, class competitions and formal competition.

\subsection{Procedures}

A modified version of the Situational Motivation Scale (SIMS) described by Guay and Vallerand (2000) was used to measure the students' motivational responses to various phases of their seasons. The SIMS was found to be a valid and reliable instrument, and is suitable for measuring situational the students motivation across diverse physical activity contexts (Standage et al., 2003; Sinelnikov, Hastie, \& Prusak, 2007). The scale involved students responding to 16 statements on a 7-point Likert scale. Questions related to one of four dimensions of situational motivation and each of which is composed of 4 questions. (1) intrinsic motivation (IM) (e.g., "Because I think it is very interesting to play volleyball”); (2) internal regulation (IR) (e.g., "Because I think this officiating is good for me"); (3) external regulation (ER) (e.g., "Because it is something that I have to do"); and (4) amotivation (AM) (e.g., "I take part in this match, but I am not sure if it is worthy"). Students were read a consistent script providing instructions on how to complete the questionnaire in all three settings.

The questionnaire was evaluated by the traditional method, and the validity of the questionnaire was 0.83 . Using Person correlation analysis, the reliability of the questionnaire was $0.812, p<0.01$. All the students completed the questionnaire at the end of the first class and the last class, and 236 questionnaires were applied to data analysis. 


\subsection{Data Analysis}

The 16 items of the SIMS were reduced to four subscales (IM, IR, ER, and AM), and internal consistency for each of the four subscales was determined using the Cronbach alpha technique in Spss 17.0. All of the subscales had 4 items, respectively. The Self-Determination Index (SDI) was calculated using the following formula: SDI $=2 * \mathrm{IM}+\mathrm{IR}-\mathrm{ER}-2 * \mathrm{AM}$ (for a complete description, see Pelletier, Fortier et al., 1995). Higher SDI scores suggest students are more self-determined (i.e., more intrinsically motivated), while lower scores indicate students' participation is less intrinsically motivated and more amotivated.

Group differences for gender, grade, and participant role during the season were determined using the Spss 17.0 of one-way analysis of variance (ANOVA). Each of the four subscales of the SIMS inventory and the measure of SDI were included as dependent variables. An alpha level of $p<0.05$ was used to determine statistical differences between groups. Effect sizes were also calculated for gender and grade levels.

\section{Results}

\subsection{Reliability and Internal Consistency}

The distributions of all scores were found to be normal, and all subscales showed internal consistency scores above 0.70 (Before and after experiment, $\alpha$ is equal to 0.75 and 0.80 respectively). Before experiment, the reliability of SIMS was as follows: IM $\alpha=0.81$, IR $\alpha=0.69$, ER $\alpha=0.61$, and $\operatorname{AM} \alpha=0.72$; after experiment, the reliability of SIMS was as follows: IM $\alpha=0.82$, IR $\alpha=0.72$, ER $\alpha=0.63$, and $\operatorname{AM} \alpha=0.77$. All the sub scales show the internal consistency is more than 0.60 , which indicates that the scale is valid.

\subsection{Self-Determination Index}

1) Comparison of SDI before experiment

Table 2 provides the means and standard deviations for the SDI and significant differences test across different grades, gender before experiment. Significant differences across grade and gender level were not observed for SDI $(p>0.05)$ respectively. The contrast of the SDI across grade and gender is to show that, if teacher do not change the teaching model, students' self-motivation will not improve. So there is no comparison of SDI across grade and gender between the traditional teaching model and SEM sport education model. That is, because there is no significant difference across the grades, it is not necessary to set up the control group.

2) Comparison of SDI across the experiment

The comparison of SDI before and after experiment can shows that the effect of the motion model. Table 3 provides the means and standard deviations for the SDI and significant differences test across experiment. Significant group differences for the SDI indicated that students were more self-determined during the Sport Education season than the traditional teaching. It shows that the SEM can significantly improve the students' self-motivation, and it is very significant to cultivate students' self-motivation.

Table 2. Comparison of grades and gender before the experiment.

\begin{tabular}{cccccc}
\hline & & M & SD & t & \\
\hline \multirow{3}{*}{ Grade } & $1^{\text {st }}$ grade & 6.99 & 3.22 & 0.13 & $>0.05$ \\
& $2^{\text {nd }}$ grade & 6.89 & 2.83 & & $>0.05$ \\
\hline
\end{tabular}

Table 3. Comparison of SDI after experiment.

\begin{tabular}{cccc}
\hline & $\mathrm{M}$ & $\mathrm{SD}$ & $\mathrm{t}$ \\
Traditional model & 6.94 & 3.31 & -12.23 \\
Sports education model & 11.65 & 3.19 & $<0.01$ \\
\hline
\end{tabular}


3) Comparison of Self-Determined Indexes across the grade, gender after experiment.

Means, standard deviations, significance levels for the SDI across grade, gender are shown in Table 4. Significant group differences for grade on the SDI indicated that there were no significant differences based on grade level during the Sport Education season $(p>0.05$, and there were no significant differences between the boys and girls $(p>0.05)$.

4) Comparison of Situational Motivation Response across the grade, gender after experiment

Means, standard deviations, and significance levels for the SIMS subscales across grade level, are shown in Table 5. By the independent sample $\mathrm{T}$ test showed that significant differences across grade level were observed for ER $(p<0.05)$. The result shows that the $2^{\text {nd }}$ grade is less influenced by external factors than $1^{\text {st }}$ grade.

Means, standard deviations, and significance levels for the SIMS subscales across gender level, are shown in Table 6. By the independent sample $\mathrm{T}$ test showed that significant differences across grade level were observed for IR $(p<0.05)$. The result shows that the boys is easier to have an interest in sports education mode than the girls.

\section{Discussion}

This study investigated the situational motivation of students during their participation in a Sport Education season. SEM provides a game, a competition environment, and promotes students to participate in physical education. This study is embodied in the following three aspects.

\subsection{SEM Focuses on the Setting of Teaching Environment}

The study shows that the SEM improved the students' motivation to participate in physical education. A number of researchers have also reached the same results. Wallhead, Garn et al. (2014) reported that high school students have more sports motivation and more entertainment during the sports education model than the tradition one. Perlman (2010) showed that Sport Education significantly increased amotivated students' enjoyment and satisfaction of teamwork in physical education. Although encouraging, Wallhead et al. (2013) believe that, Perlman's study were limited by students' expression of feelings. Only the adaptability between feelings expression and behavior is proved, can we prove that Sport Education model including motivational model. Tristan Wallhead et al. carry out teaching experiment of the team handball season mode, have demonstrated that when amotivated students and higher motivated students were arranged at one team by setting the engagement rules in complex game or competition environment, each students can get a higher success rate, and this also increased the self-motivation of amotivated students. Shen et al. (2009) also suggested that to achieve this goal, teaching strategies should focus on improving students' learning experience during games. Amotivated students' degree of involvement and success rates should be observed. So, author suggests that sport education should foster student's learning experience under the game environment.

Table 4. Comparison of between the grades and gender SDI before the experiment.

\begin{tabular}{ccccc}
\hline & & $\mathrm{M}$ & $\mathrm{SD}$ & $\mathrm{t}$ \\
\hline \multirow{2}{*}{ Grade } & $1^{\text {st }}$ grade & 11.70 & 4.02 & 0.13 \\
& $2^{\text {nd }}$ grade & 11.59 & 3.63 & 3.98 \\
Gender & Boys & 11.89 & 3.77 & 0.53 \\
& Girls & 11.45 & $>0.05$ \\
\hline
\end{tabular}

Table 5. Comparison of situational motivation response across the grade.

\begin{tabular}{|c|c|c|c|c|c|c|}
\hline & \multicolumn{2}{|c|}{$1^{\text {st }}$ grade } & \multicolumn{2}{|c|}{$2^{\text {nd }}$ grade } & \multirow{2}{*}{$\mathrm{t}$} & \multirow{2}{*}{$p$} \\
\hline & M & $\mathrm{SD}$ & $\mathrm{M}$ & SD & & \\
\hline IM & 5.82 & 0.91 & 5.66 & 1.14 & 0.71 & $>0.05$ \\
\hline IR & 5.53 & 0.88 & 5.43 & 0.97 & 0.49 & $>0.05$ \\
\hline ER & 1.88 & 0.81 & 1.55 & 0.71 & 2.01 & $<0.05$ \\
\hline $\mathrm{AM}$ & 1.80 & 0.97 & 1.81 & 0.89 & -0.04 & $>0.05$ \\
\hline
\end{tabular}


Table 6. Comparison of situational motivation response across the gender.

\begin{tabular}{|c|c|c|c|c|c|c|}
\hline & \multicolumn{2}{|c|}{ Boys } & \multicolumn{2}{|c|}{ Girls } & \multirow{2}{*}{$\mathrm{t}$} & \multirow{2}{*}{$p$} \\
\hline & $\mathrm{M}$ & $\mathrm{SD}$ & M & SD & & \\
\hline $\mathrm{IM}$ & 5.92 & 0.90 & 5.62 & 1.07 & 1.41 & $>0.05$ \\
\hline IR & 5.68 & 0.83 & 5.23 & 0.95 & 2.34 & $<0.05$ \\
\hline ER & 1.82 & 0.76 & 1.70 & 0.81 & 0.71 & $>0.05$ \\
\hline $\mathrm{AM}$ & 1.91 & 1.02 & 1.71 & 0.86 & 0.97 & $>0.05$ \\
\hline
\end{tabular}

The research scope of students' motivation training under SEM is very extensive, involves improving student's extracurricular activities participation level (Wallhead, Garn, \& Vidoni, 2014), culturing amotivated students of self-motivation research (Wallhead et al., 2013; Pelletier et al., 1995) and so on, in China Xiong Yan et al. (2013) implemented aerobics SEM for college students, and improved the students' self-motivation. Our study takes the college students as the research object, through the implementation of the volleyball Sports Education Season Mode, training and improving the students' motivation.

\subsection{SEM Meets the Psychological Needs of Students}

Sports Education Season can stimulate the students' perceptions of responsibility, and improve the motivation of students to participate in physical education. The results of this study show that there was no significant difference between the grades in Sports Education Season experiment. Experimental result of this study supported earlier result of Sinelnikov et al. (2007) that there was no difference in grades, but don't support the result that the boys' SDI was significantly higher than girls. But our study supported that SDI was no significant difference between boys and girls. To implement the seasons of Sports Education, boys and girls were highly motivated to participate, not only in practice and game play, but also in officiating roles. Such as management, players, records, referee in practice and in games, or on the player character of setter, attacker, and libero. Students can engage in activities freely they gain interests and enjoy learn and finish the task. This is the characteristic of a high level intrinsic motivation. Thus, sports education can provide students real exercise experience and team work environments advantages (Sinelnikov, Hastie, \& Prusak, 2007). Hastie (2000) suggested that SEM is an ecological framework, this program of action is driven by structure feature that is "inherent content-embedded accountability" "where role responsibility fulfillment and games”, “count toward a season outcome”, students tend to take seriously only that work for which they are held accountable. SEM makes students aware of the task, including the perception of the environment and the perception of autonomous decision, thus enhancing the students' motivation to participate in Physical Education (Wallhead et al., 2004).

Many researchers believe that SEM promotes students to get psychological satisfaction, improving students' self-motivation. SEM provides students with sports expectations and expectations of the needs to meet. In addition, physical education teachers support students’ psychological needs, and predict the students' need satisfaction which is associated with greater self-motivation, participation in sports in the physical education class in future (Chang, Hsu, \& Lin, 2009). Different from the previous quantitative research, Perlman (2010) mainly used the interview method and analysis of video quality to examine students' perceptions of sports education, and the perception of teachers' experience, and by analyzing the views of students and teachers, study suggests that the SEM supports the students’ psychological need for relatedness, competence and autonomy, and found that the support is a specific internalization factor to improve students' autonomy.

In this study, two formal competitions have been arranged among the $10^{\text {th }}$ weeks and the $18^{\text {th }}$ weeks. This SEM of volleyball teaching provide students with psychological needs by arrangement students to take part in the competition and celebrate festivity after the competition (1) Relatedness. The initial impetus for the team is to focus on the feeling and expression of the students with low skill levels, which allows the student to develop appropriation of peer relations and the identity of the peer. This is the foundation of teamwork. (2) Competence. Two formal competitions have provided opportunities for students a variety of sports and possible execution ability, to support student achievement orientation (i.e. task and self-performance) and to support student to display their competence of opportunity (such as the role, winning the game and so on). Compared with the traditional teaching model, students feel a higher level of competence (such as the technical stability in the rapid changing of the game environment) and the actual success of the technical stability. (3) Autonomous. To support 
students in the game were in their own behavior, independent support made students for the development of more fair rules of the game, Therefore, enhanced the students’ ability of self-decision.

\subsection{A High Level of Motivation to Experience a Process of Sports Education Season}

In this study, students through the teaching process of SEM in whole season, shows that freshman has higher ER level than sophomore, and there is a significant relationship between grades and ER. As a result, the intrinsic motivation of freshman is easier to be affected by external factors. It is probably reason that the sophomore has a longer period of volleyball sport, after has process of changes in whole season, showed a stronger motivation. Silva et al. (2010) the SEM of intervention clearly emphasized enjoyment, mastery, and challenge which are the process of sports, not the aim. IM develops students to become the participants who appreciate sports culture, and have the ability and enthusiasm (for sport), the sports become a export providing students with the activation of motivation and skills. Thus, students will never abandon sports. This fact actually does not exceed the scope of the curriculum plan, but is the task of curriculum planning needs to be completed. Therefore, the researchers believe that the SEM is an iterative method of physical education teaching methods (Wallhead, Garn, \& Vidoni, 2014; Wallhead et al., 2013).

For many years, Chinese physical education is influenced by viewpoint of "Exercise technique and body building”, "theory of physical condition", "theory of technical ability", which regard "the teaching exercise technique", or "body building” as the goals of the PE. Recently, some scholars have pointed the benefits of SEM, such as "role function”, "team identity", "share success and failure”, and so on. Positive emotional results optimize the structure of physical education, so that students follow the direction of the motivation to meet the psychological need of the students’ autonomy, competence, communication (Liu, Liu, \& Dong, 2015). Study, which is focus on allowing students to enjoy the competition, enjoying the fun of sports and truly involved in the experimental study is rarely. This study shows that the Chinese students are very pleasure to accept the sports education season mode in emotionally, not only it is an extremely new approach, but also offer a new idea for sports class in China, that is how to cultivate students have more interest in sports, and enjoy the benefits from sports.

Limitations of the study and directions for future research: The objects in this paper limited in freshmen and sophomore who are lack of systematic Volleyball training and learning. The Sport Education Model will be more effective if students with a deep understanding of Volleyball professional knowledge. The future research will emphasize on other curriculum design, such as track and field which focus on individual physical development.

\section{Conclusion and Suggestion}

In conclusion: Sport education provides competitively environment, increasing students' different motivation levels to participate in the PE. Volleyball sport education season model enhanced students' intrinsic motivation strongly. The sport intrinsic motivation and student perception are in positive relation. To meet students' psychological needs since they prefer to pay more efforts, ability and communication, they will put more time and energy in PE.

There are no much differences between people in different gender and age and the model has been adopted to fit in different conditions. It helps the model to make more widespread.

But, the cultivation of student's motivation is a comprehensive process during PE. Team sports and individual sports may cause student having temporary periodic wave motion. Thus, developing different model for different field of sport in classes should be considered.

\section{References}

Centers for Disease Control and Prevention (CDC) (1999). Youth Risk Behavior Surveillance: National Alternative High School Youth Risk Behavior Survey (pp. 1-96). Government Report. Atlanta, GA: CDC.

Chang, K. K. L., Hsu, P. S., \& Lin, C. P. (2009). A Qualitative Integration of Self-Determination Theory and ExpectationConfirmation Theory Using Physical Education as an Example. Quality \& Quantity, 43, 977-981. http://dx.doi.org/10.1007/s11135-008-9166-y

Chen, A. (2001). A Theoretical Conceptualization for Motivation Research in Physical Education: An Integrated Perspective. Quest, 53, 35-58. http://dx.doi.org/10.1080/00336297.2001.10491729 
Deci, E. L., \& Ryan, R. M. (2000). The "What” and "Why” of Goal Pursuits: Human Needs and the Self-Determination of Behavior. Psychological Inquiry, 11, 227-268. http://dx.doi.org/10.1207/S15327965PLI1104_01

Guay, F., Vallerand, R. J., \& Blanchard, C. (2000). On the Assessment of Situational Intrinsic and Extrinsic Motivation: The Situational Motivation Scale (SIMS). Motivation and Emotion, 24, 175-213. http://dx.doi.org/10.1023/A:1005614228250

Haerens, L., Kirk, D., Cardon, G. et al. (2010). Motivational Profiles for Secondary School Physical Education and Its Relationship to the Adoption of a Physically Active Lifestyle among University Students. European Physical Education Review, 16, 117-139. http://dx.doi.org/10.1177/1356336X10381304

Hastie, P. A. (2000). An Ecological Analysis of a Sport Education Season. Journal of Teaching in Physical Education, 19, 355-373.

Kinchin, G. D. (2001). A High Skilled Pupil’s Experiences with Sport Education. The Australian Council for Health, Physical Education, and Recreation Healthy Lifestyles Journal, 47, 5-9.

Liu, Y. N., Liu, J., \& Dong, C. X. (2015). Moral Education Research Based on Sport Education Model with the View of Moral Sociology. Journal of Beijing Sport University, 38, 89-94.

Markland, D., Ryan, R. M., Tobin, V. J. et al. (2005). Motivational Interviewing and Self-Determination Theory. Journal of Social and Clinical Psychology, 24, 811-831. http://dx.doi.org/10.1521/jscp.2005.24.6.811

Ntoumanis, N., Pensgaard, A. M., Martin, C. et al. (2004). An Idiographic Analysis of Amotivation in Compulsory School Physical Education. Journal of Sport and Exercise Psychology, 26, 197-214.

Pelletier, L. G., Fortier, M. S., Vallerand, R J. et al. (1995). Toward a New Measure of Intrinsic Motivation, Extrinsic Motivation, and Amotivation in Sports: The Sport Motivation Scale (SMS). Journal of Sport and Exercise Psychology, 17, 35.

Perlman, D. (2010). Change in Affect and Needs Satisfaction for Amotivated Students within the Sport Education Model. Journal of Teaching in Physical Education, 29, 433-445.

Perlman, D. J. (2011). Examination of Self-Determination within the Sport Education Model. Asia-Pacific Journal of Health, Sport and Physical Education, 2, 79-92. http://dx.doi.org/10.1080/18377122.2011.9730345

Perlman, D., \& Goc Karp, G. (2010). A Self-Determined Perspective of the Sport Education Model. Physical Education and Sport Pedagogy, 15, 401-418. http://dx.doi.org/10.1080/17408980903535800

Ryan, R. M., Kuhl, J., \& Deci, E. L. (1997). Nature and Autonomy: An Organizational View of Social and Neurobiological Aspects of Self-Regulation in Behavior and Development. Development and Psychopathology, 9, 701-728. http://dx.doi.org/10.1017/S0954579497001405

Shen, B., McCaughtry, N., \& Martin, J. J. et al. (2009). Motivational Profiles and Their Associations with Achievement Outcomes. Journal of Teaching in Physical Education, 28, 441-460.

Silva, M. N., Markland, D., \& Vieira, P. N. et al. (2010). Helping Overweight Women Become More Active: Need Support and Motivational Regulations for Different Forms of Physical Activity. Psychology of Sport and Exercise, 11, 591-601. http://dx.doi.org/10.1016/j.psychsport.2010.06.011

Sinelnikov, O. A., Hastie, P. A., \& Prusak, K. A. (2007). Situational Motivation during Seasons of Sport Education. ICHPER-SD Journal of Research, 2, 43-47.

Spittle, M., \& Byrne, K. (2009). The Influence of Sport Education on Student Motivation in Physical Education. Physical Education and Sport Pedagogy, 14, 253-266. http://dx.doi.org/10.1080/17408980801995239

Standage, M., Treasure, D. C., \& Duda, J. L. et al. (2003). Validity, Reliability, and Invariance of the Situational Motivation Scale (SIMS) across Diverse Physical Activity Contexts. Journal of Sport \& Exercise Psychology, 25, 19-43.

Wallhead, T. L., \& Ntoumanis, N. (2004). Effects of a Sport Education Intervention on Students’ Motivational Responses in Physical Education. Journal of Teaching in Physical Education, 23, 4-18.

Wallhead, T. L., Garn, A. C., \& Vidoni, C. (2014). Effect of a Sport Education Program on Motivation for Physical Education and Leisure-Time Physical Activity. Research Quarterly for Exercise and Sport, 85, 478-487. http://dx.doi.org/10.1080/02701367.2014.961051

Wallhead, T., Garn, A. C., \& Vidoni, C. et al. (2013). Game Play Participation of Amotivated Students during Sport Education. Journal of Teaching in Physical Education, 32, 149-165.

Xiong, Y., \& Ma, H. T. (2013). The Influence to Students' Sports Motivation by Sport Education Model. Journal of Nanjing Sport Institute, 27, 82-90. 


\section{Submit or recommend next manuscript to SCIRP and we will provide best service for you:}

Accepting pre-submission inquiries through Email, Facebook, LinkedIn, Twitter, etc.

A wide selection of journals (inclusive of 9 subjects, more than 200 journals)

Providing 24-hour high-quality service

User-friendly online submission system

Fair and swift peer-review system

Efficient typesetting and proofreading procedure

Display of the result of downloads and visits, as well as the number of cited articles

Maximum dissemination of your research work

Submit your manuscript at: http://papersubmission.scirp.org/ 